\title{
Design and Implementation of the Human Capital Report: The Case of the Biomedical Branch of the University of Florence
}

\author{
Cristiana Parisi', Paola Rossi ${ }^{2 *}$ \\ ${ }^{1}$ Department of Operations Management, Copenhagen Business School, Copenhagen, Denmark \\ ${ }^{2}$ Department of Economics and Management, University of Trento, Trento, Italy \\ Email:cp.om@cbs.dk, "paola.rossi-1@unitn.it
}

Received 3 June 2016; accepted 16 July 2016; published 19 July 2016

Copyright (C) 2016 by authors and Scientific Research Publishing Inc.

This work is licensed under the Creative Commons Attribution International License (CC BY).

http://creativecommons.org/licenses/by/4.0/

(c) () Open Access

\begin{abstract}
The purpose of this paper is to develop a Human Capital Report focused on the competency profile of the key employees. Employing the case study of Biomedical Branch of University of Florence, we have designed a strategy map centred on key stakeholders: students, university, didactic and research centres, businesses. Furthermore, we have designed a model for the management of human resources, integrating two different approaches: individual and organic. On the basis of this model, semi-structured interview was carried out to obtain rich data on the current competences of key employees, divided in three personal characteristics for each strategic theme: knowledge, skills, aptitudes. The results of our analysis show where the competences of the key personnel are lacking, the strategic initiatives to take in the future, and the lead indicators to use for measure the effects of the initiatives. This study contributes to the previous literature, describing how university institutes can measure the human capital readiness.
\end{abstract}

\section{Keywords}

Human Resources, Strategy Maps, University

\section{Introduction}

The rapid development of the Italian public sector in general and of universities in particular (as a result of their increased financial, normative and didactic autonomy), and the changes which the competitive environment in question has undergone, call for a deeper analysis of the many variables determining such institutions' results.

Given the greater and widely-perceived competitiveness of the field, Italian universities are well aware of the

${ }^{*}$ Corresponding author.

How to cite this paper: Parisi, C. and Rossi, P. (2016) Design and Implementation of the Human Capital Report: The Case of the Biomedical Branch of the University of Florence. Theoretical Economics Letters, 6, 628-639.

http://dx.doi.org/10.4236/tel.2016.64068 
need to increase their internal efficiency, as well as the effectiveness of the services offered to stakeholders, so as to increasingly optimize their performances.

The literature review on performance management and evaluation for University as public organization has focused on the application of Balanced Scorecard and Strategy Maps to improve the business competitiveness. None of these studies have investigated the implementation of strategy maps for intangible assets.

Given the centrality of human resources in the definition of stable processes for the creation of value in universities, the aim of this paper is to create a Strategy Map centered on key employees playing a crucial role in entities' different administrative processes, and to promote a range of initiatives aimed at developing the competences of universities' entire workforce.

This study is based on the case study of Biomedical Branch of Florence University that has splitted its central administrative unit in five administrative branches offering general supporting services to didactic and research centers (UADRs). Semi-structured close interviews were formulated in order to quantify the key personnel's current competences reported in the Human Capital Report.

We have chosen one branch of the University of Florence as case study because this University has profoundly changed its organization in order to increase the efficiency of the administrative processes, where the role of human resources is central. The application of Strategy Maps could be a useful tool to measure the performance of these new organizational structures.

The remainder of this paper is organized as follows. Section 2 introduces the balanced scorecard in the non-profit organizations and presents the most significant literature review on the application of balanced scorecard and strategy maps to university institute. Section 3 describes the methodology and the framework for designing a strategy map for university, the competency profile and the human capital report. Finally, this research is concluded in Section 4.

\section{Literature Review}

\subsection{Concept of Strategy Map in Non-Profit Organizations}

The strategy maps are a tool developed to illustrate the objectives and the cause effect relationships between the BSC perspectives [1]. Strategy Maps have been developed for insurance companies, banks, health companies, manufacturing companies and many other non-profit organizations.

Being originally designed for profit organizations, strategic maps have been retailored over time so as to be used in public entities, where financial considerations represent a limit rather than an aim (although said organizations must certainly monitor their expenses). The main differences between the private and the public sector in the application of strategy maps pertain to:

- the aim of Strategy Maps;

- strategic adjustment;

- the importance of the four perspectives;

- the definition of the four perspectives;

- assessment problems.

Strategy Maps are generally used in private companies for the management of performances; in public companies, however, they can also be used to create a reporting system addressed to such companies' many stakeholders. As a matter of fact, public companies have precise budget limits regulated by central authorities, being thus compelled to create an external reporting system. Strategy Maps are therefore seen as an organic structure necessary to select given indicators, as an accounting and reporting system for external stakeholders and, ultimately, as an instrument for comparison between different organizations.

In the private sector, Strategy Maps are viewed as an instrument to suit single corporate departments to the entire company's strategic aims; quite differently, given the multiplicity and complexity of services to be supplied and the variety of stakeholders whose needs are to be satisfied, Strategy Maps in the public sector are applied to single organizational sub-units or services, independently of the entire organizational structure.

The definition itself of "client" is particularly difficult in the public sector, not only because each service may be produced for a different section of the public with different characteristics and needs, but also because it implies a differentiation between donors, i.e. institutions financing the organization's activities, and clients, i.e. the recipients of services.

As regards the four perspectives of the balanced scorecard (financial, customer, internal process perspective, learning and growth), these have been devised for the private sector in order to evaluate performances whilst 
going beyond exclusively financial considerations. Quite clearly, the hierarchy which Strategy Maps imply has no relevance within public organizations, in that the financial perspective is not the latter's primary goal, these rather aiming at satisfying their clients' needs. It follows that financial effectiveness acquires significance only as a means to offer clients greater value through public investments or to preserve an economic-financial balance.

The terminology used to describe the four perspectives is itself not suited to the public sector:

- the definition of clientele is particularly problematic in a public entity, in that public authorities must satisfy a wide range of clients and must account for their performances to tax-payers, to the central government and to controlling and auditing agencies;

- client satisfaction provides more information to the private than to the public sector;

- growth and learning are indeed important in the public sector, though not as strategic aims to be achieved,

- rather as means to limit costs;

- similarly, the word "processes" is not commonly used within the public sector.

Another problem within the public sector is the assessment of immaterial assets, such as the quality of life and services. These represent the prime strategic goals of public entities, yet their assessment may be lengthy and thus cast doubt over the usefulness of Strategy Maps for management purposes.

In devising and perfectioning Strategy Maps for the public sector, it was first believed that their use could bring about tangible and intangible benefits. Yet, while some organizations have accepted such instruments as a means to give further value to services rendered to the community, other entities have not been open to their adoption, both because they entail investments in terms of time and efforts, and because it is very difficult to predict whether the use of strategy maps can bring a visible and tangible contribution to the management of business.

\subsection{Balanced Scorecard and Strategy Maps in Universities}

Few studies have investigated the implementation of BSC and Strategy Maps in universities. [2] has developed an Academic Scorecard identifying for perspectives: academic perspective instead financial perspective, stakeholders perspective instead customer perspective, international business and innovation and learning perspective as the original balanced scorecard. Following the conclusions of [2], [3] emphasizes the complexity of a BSC for the university and the need to synthesize the faculty objectives in a single structure manner. Other studies ([4], [5]) have proposed the use of BSC as a tool for implementing strategic performance measurement system at universities and to increase the operational efficiency. Differently from the previous researches, [6] has developed a balanced scorecard approach to link the strategy of educational institutions with the regional objectives.

[4] and [7] have developed a strategy map putting mission and vision on the first, and then the other perspective of the BSC. On the contrary, [8] has personalized the perspective of the BSC, modifying the Stakeholders perspective with the People Development, the Internal process perspective with the Institute Capability, the Learning and growth perspective with the Research Output. But none of them have explored the ability of the intangible assets to help the university implement its strategy.

In this study we intend to describe how develop a human capital report in university, creating a strategy map for university based on personnel competency profile.

\section{The Case of Biomedical Branch of University of Florence}

\subsection{Methodology}

In this research, the Biomedical Branch of University of Florence is selected as the example. First we have defined the four perspective of BSC based on the literature review (Figure 1 and Table 1), then we have developed a model to identify the personnel's competences (Figure 2). Finally, the human capital report (Table 2) is developed quantifying the key personnel's current competences by carrying out semi-structured close interviews with a significative number of employees working in financial or research offices, and by collecting direct opinions and impressions, in line with a 360 degree feedback technique. Interviewees were asked to rate (from zero to five) a number of statements; the entity's management was then asked to express the level of competence deemed appropriate thereby in the same way. This allowed for the quantification of the actual adequacy of human resources and for its expression by percentages.

\subsection{Biomedical Branch of University of Florence Background}

Over the last ten years, the dimensional development of universities has enlarged the activities carried out by the 


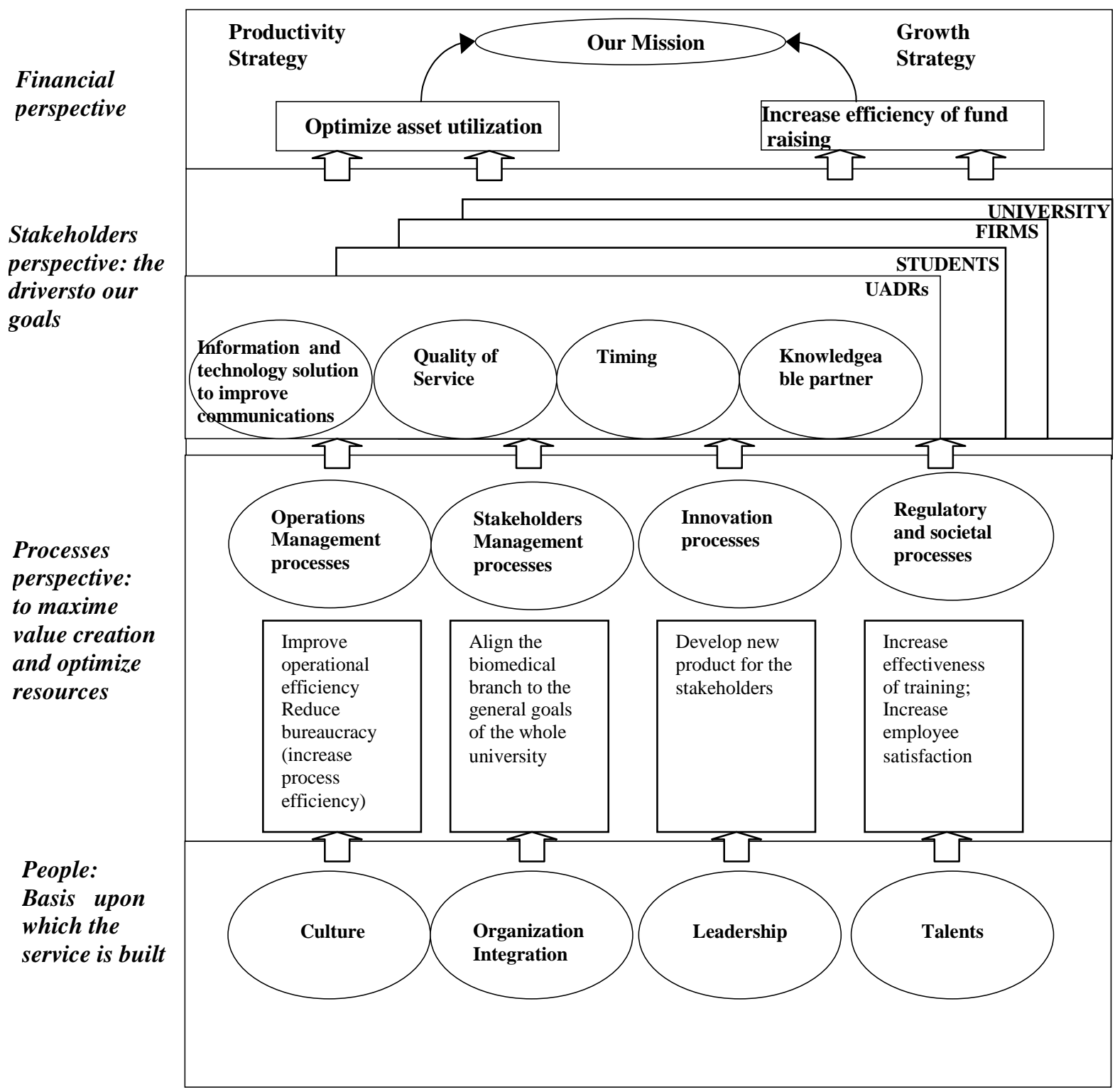

\section{Figure 1. The strategy map of the biomedical branch.}

latter's central administrative structures, whose original supporting role within the main productive process has significantly been widened. In certain instances, like at the University of Florence, such a process has led to the unrestrained growth of academic structures, together with ensuing inefficiencies resulting from the multiplication of their activities and the excessive bureaucratization of their processes.

Hence, with the aim of easing the operativeness of its central administration, the Board of Governors of the University of Florence resolved on June 22, 2001 and on December 3, 2001 to split its central administrative unit in five administrative branches: the scientific and technical branch of Careggi, the scientific branch of Sesto, the social sciences branch, the historical centre branch no. 1, and the historical centre branch no. 2/agrarian sciences. Said branches are to be viewed as structures offering general supporting services to didactic and research centres (UADRs) with the aim of:

- further integrating and giving value to their assigned human, financial and instrumental resources;

- managing, in line with transparent and programming criteria, their assigned financial resources, in order to optimize their services;

- uniforming and simplifying processes by using computerized systems. 
Table 1. The stakeholders' perspective.

\begin{tabular}{|c|c|c|c|}
\hline STUDENTS & UNIVERSITY & UADRS & BUSINESSES \\
\hline $\begin{array}{l}\text { Improved consultancy and } \\
\text { guiding services relating to } \\
\text { the labour market }\end{array}$ & $\begin{array}{l}\text { Innovative methodologies } \\
\text { improving the integrated } \\
\text { management of resources }\end{array}$ & $\begin{array}{l}\text { New computerized } \\
\text { systems to improve } \\
\text { communication with the } \\
\text { Branch }\end{array}$ & $\begin{array}{l}\text { More flexible research } \\
\text { contracts }\end{array}$ \\
\hline $\begin{array}{l}\text { Increased number of stages, } \\
\text { training and guiding services }\end{array}$ & $\begin{array}{l}\text { Computerized systems to } \\
\text { ensure greater transparency } \\
\text { and visibility in the use of } \\
\text { assigned resources }\end{array}$ & $\begin{array}{l}\text { Punctual supply of } \\
\text { services rendered by the } \\
\text { Branch }\end{array}$ & $\begin{array}{l}\text { Creation of university } \\
\text { enterprises workshops to } \\
\text { promote research }\end{array}$ \\
\hline $\begin{array}{c}\text { Tailored technological } \\
\text { services and assistance } \\
\text { provided to 1st year } \\
\text { students and foreign students }\end{array}$ & $\begin{array}{c}\text { Programming and planning } \\
\text { the activities of the Branch } \\
\text { in line with the University's } \\
\text { main goals }\end{array}$ & $\begin{array}{l}\text { Greater coordination and } \\
\text { integration with the } \\
\text { Branch }\end{array}$ & $\begin{array}{l}\text { Reduced bureaucratization of } \\
\text { processes relating to the } \\
\text { management of relationships } \\
\text { with external businesses }\end{array}$ \\
\hline $\begin{array}{l}\text { Efficient management of } \\
\text { payments and collections by } \\
\text { grant-holders, doctoral } \\
\text { students and students } \\
\text { acquiring a specialization }\end{array}$ & $\begin{array}{l}\text { Increased financial } \\
\text { autonomy }\end{array}$ & $\begin{array}{l}\text { Better services offered by } \\
\text { the Branch }\end{array}$ & $\begin{array}{l}\text { Adjustment of research to the } \\
\text { needs of the market and of } \\
\text { enterprises }\end{array}$ \\
\hline
\end{tabular}

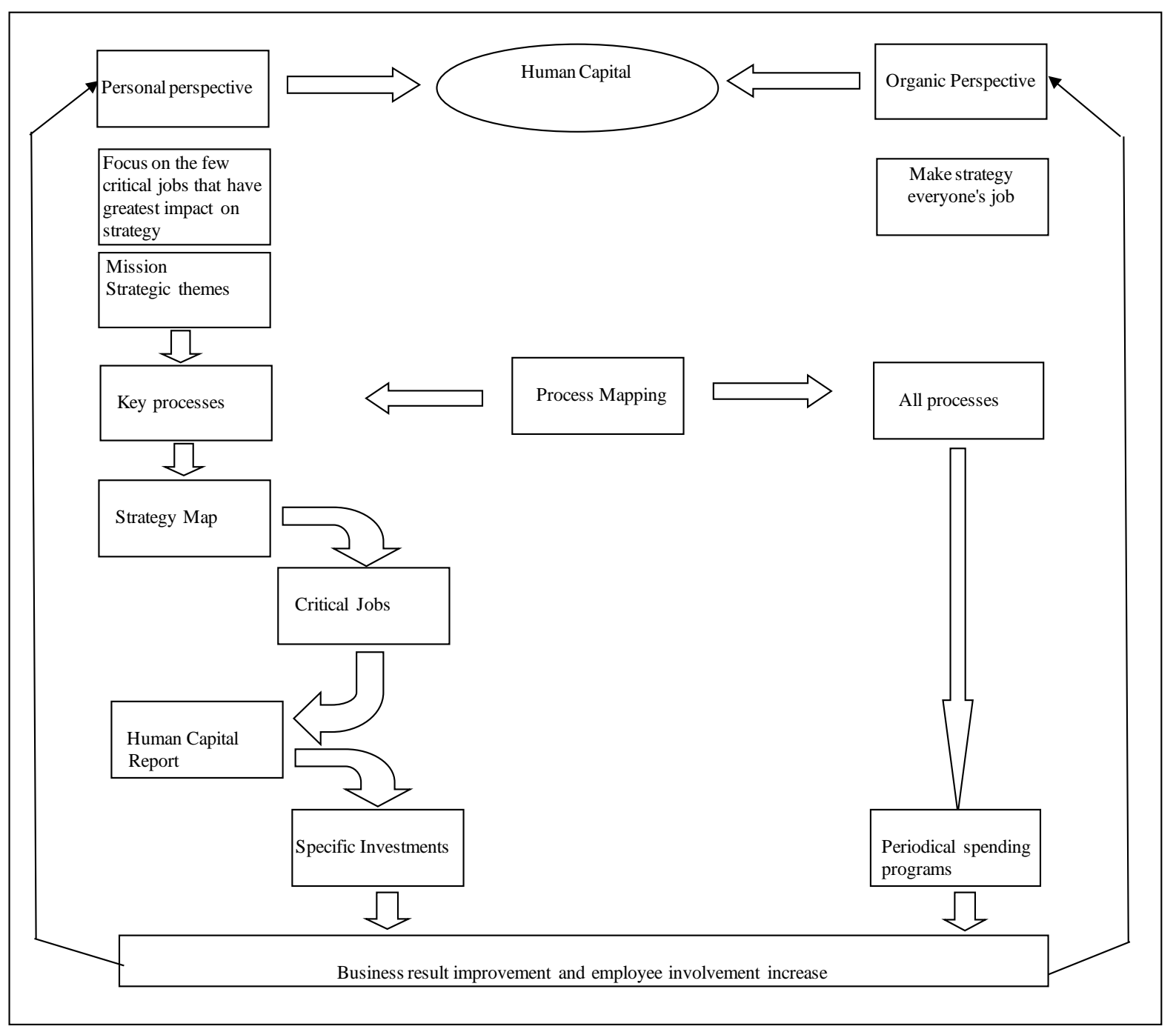

Figure 2. Model for the management of human resources. 
Table 2. Human capital report.

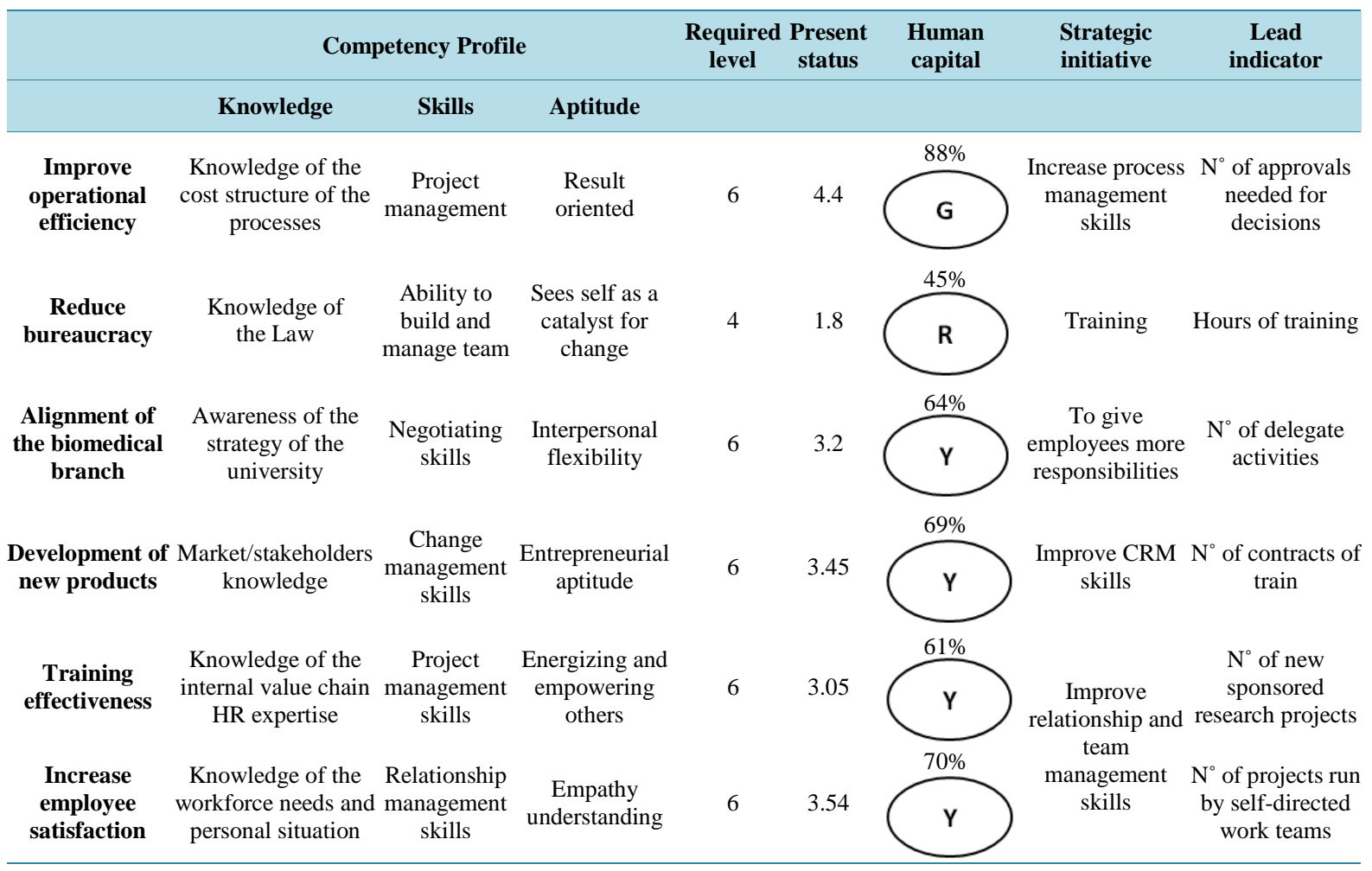

The University's branches provide functional services to UADRs (faculties, departments, research centres, libraries, museums) with respect to:

- general affairs;

- financial services;

- didactic services and services for students;

- research and international relations services;

- technical and patrimonial services.

Not only may UADRs ask to be assigned to a branch different from that established therefore, but they may also delegate their own competences to the branch itself, supplying it with any required resources.

As regards the branches' finances, their revenues derive from transfers (entered in the University's Budget) and from eventual autonomous revenues decided and/or authorized by the Board of Governors.

Our study focuses on the management of human resources in the Biomedical Branch, which is divided into the following offices (we hereby list only their primary activities):

- general affairs office: management, programming and planning the needs and resources of the concerned branch, innovating processes and methods, relationships with health and hospital institutions, management of legal services, consultancies and insurance service management of communication services;

- financial services office: budget registration and management, elaboration of budget structure in CIA, monitoring credits and managing proceeds, monitoring receipts, accounting, inventories, remuneration of personnel, issue of debit notes, active invoices and registration, revenues, management of VAT books, customs' declarations, management of UADRs directly pertaining to the branch;

- research services office: supporting activities for the presentation of proposal and expense plans of international projects, supporting technological and divulging activities regarding applications for funds, research registries, procedures for the mobility of foreign students and Italian students engaged abroad, procedures relating to the award of Masters, research grants and management of graduates' careers;

- didactic services office: supporting activities for didactic structures and management of students' careers, services for students, territorial network, student centres, management of assistance services for first-year students, tutoring, training and guiding stages, crediting and certifying quality, supporting activities for post-graduate 
training, personnel training and updating;

- patrimonial and technical office: management of all movable, immovable and technical assets of the branch.

Our detailed analysis of the quality, efficiency and effectiveness of the services rendered by the Branch has highlighted a number of problems as to e.g. the integrated reorganization of activities, the resistance to change manifested by administrative personnel pertaining to UADRs - this not having had the chance to experience, as from the beginning, a harmonic and shared working environment - the relationship between the branch and UADRs, the lack of sufficient human and financial resources, the creation of an expenses plan system for EU projects (also through the use of computerized systems), and the planning of instruments capable of monitoring activities and evaluating their results.

\subsection{The Strategy Maps of Biomedical Branch}

The application of the strategy map to the Biomedical Branch is grounded upon an analysis of the aims to be pursued. The model is designed to introduce the cultural change needed to promote and guide the University's corporate-like transformation, and thus to increase its capacity to generate value for its stakeholders, to allocate resources and to rationalize its internal management processes.

As for the creation of value, this is generally associated in the public sector with the provision of services positively dealing with socio-economic concerns [9]. The concept of value thus assumes a specific meaning in this field, in that it relates to a complex network of social addressees having, quite often, conflicting interests.

As regards universities, the subjects who are mostly involved in the ambit in question are the Ministry, the Region, the Chancellors' Permanent Association, students, families, the labour market, the local community, Europe, other universities, producers of technological equipment, and the collectivity [10]. Furthermore, given that the Biomedical Branch also supplies services to UADRs, the Branch is expected to produce and render services which create value also for such stakeholders and to satisfy the needs of such entities' teaching staff.

In order to avoid ambiguous strategic orientations (which the mission then mirrors within the Branch) resulting from the need to satisfy such a numerous and differentiated group of stakeholders, our work has set a number of priorities and selected key stakeholders whose satisfaction is decisive for the results achieved by the entire structure.

In the present case, the Branch's main stakeholders are students, the University in general, UADRs and external companies with which the structure is involved [11].

By carrying out a selection, the project has established the most adequate strategic themes underpinning a valid proposal which, by satisfying the entity's main social stakeholders, can effectively implement the structure's mission. The mission coincides with supporting activities for the University's research and didactics, and represents the ultimate goal of the structure, to be pursued precisely through the definition and implementation of said strategic themes.

The themes established for the Branch in its current phase of activity are the improvement of its operative efficiency, the reduction of bureaucracy (this curbing the efficiency of internal management processes), the satisfaction of key stakeholders through the offer of innovative solutions, the structure's alignment to the strategy of the University of Florence, the development of new products and services for the structure's UADRs, and its employees' greater satisfaction.

Said strategic priorities are to be included within a strategic map, so that the causal nexus between such priorities and the implementation of the structure's mission can be evidenced. Such a representation also aims at bringing about a cultural change within the structure, in that it introduces an approach oriented to the adjustment of resources to the corporate strategy [12] [13].

As a matter of fact, all undertaken actions and decisions mirror the basic aims of the structure and need to contribute to their implementation, thus leading to a more careful appraisal of the allocation of resources and the management of corporate performances. Moreover, the need to carefully monitor internal management processes in order to create an evaluation model brings about a deeper consideration of the human factor, which appears to be crucial for the former's management.

The above described model of a strategy map is centered on the corporate mission (Figure 1), this being the corporate strategic profile and starting point for the definition of corporate policies. It is also the ultimate goal which economic-financial resources are directed to.

Said area of interest is often placed at the basis of Strategy Maps for the public sector in general and universities in particular [14], and is sometimes placed under the clients' perspective. Such a structural choice mirrors 
the non-lucrative aim of management, and the fact that financial resources, i.e. funds allocated by other entities, represent an unchangeable input of management, rather than its goal.

However, the analysis we have deemed most appropriate for the Strategy Map of the Biomedical Branch is of a traditional kind: financial considerations are placed at the top of the model, so as to underline the importance of introducing a notable change within the corporate culture by paying more attention to the economic result of management.

The latter is synthetized in two aims: "the optimized use of assets", with respect to the productivity strategy, and the "increased effectiveness of policies for the obtainment of funds", with respect to the growth strategy.

Such aims are pursued by offering key stakeholders given services characterized as in the second area of interest of the model. Such characteristics, based on the interests of the main subjects benefiting from the services produced by the Branch or being interested therein, are thus illustrated (Table 1).

The third area of interest of the Map is that pertaining to internal management processes, which illustrates the entity's selected strategic themes. These are classified in the four typologies of operative management processes, in stakeholders management processes, in innovation and regulation and social processes.

Lastly, the greatest immaterial resource of the Branch, i.e. human resources, is represented at the basis of the Strategy Map. Given the intangibility of the produced output and the importance of knowledge and skills for the services rendered, this perspective ought to focus only on this kind of immaterial asset, thus devoting its content to the "individuals" present therein [15] [16].

The fundamental elements of the management of human resources are: culture-which needs to be tailored to respond to the market's ever-changing needs-organizational integration (a crucial aim for a relatively new structure), the development of a leadership guiding the entity in its transformation, and the exploitation of talented employees who are not rightly appraised as a result of excessively bureaucratized processes inherited from the past.

\subsection{The Competency Profile}

The rapid development of the Italian public sector in general and of universities in particular (as a result of their increased financial, normative and didactic autonomy), and the changes which the competitive environment in question has undergone, call for a deeper analysis of the many variables determining such institutions' results.

Given the greater and widely-perceived competitiveness of the field, Italian universities are well aware of the need to increase their internal efficiency, as well as the effectiveness of the services offered to stakeholders, so as to increasingly optimize their performances.

Within such a complex scenario, the centrality of immaterial resources, especially human resources, is increasingly evident, in that the definition of stable processes for the creation of value over time hinges precisely upon them. As a matter of fact, the respect of preset goals and the achievement of given performance levels require a widely shared corporate culture strongly oriented to the pursuit of achievements at all organizational levels, especially at the level of single employees.

Universities, therefore, need to precisely orient their personnel's behaviour, increasing the latter's motivations and competences, in order for their widely-aimed services to be increasingly efficient, profitable and qualitatively good.

Such an effort calls for the adoption of an adequate model capable of assessing, managing and developing human resources, evaluating the contribution given thereby and defining programmes which create and increase value over time, in line with the entity's preestablished strategic policies.

The development of such a model must, however, take into account the characteristics and limits of the public sector in general and of universities in particular, these affecting both the model's conception and implementation processes, thus differentiating them from the private sector.

As regards said characteristics, attention should be paid to: the centrality of the entity's strategic approach with respect to its relationship between managerial choices and political dimension, the system's relationship with the external environment, and the latter's constitutive need to account to its stakeholders for all its actions [17]. As regards universities, attention must also be paid to the immateriality of their output.

The technical limits of the public sector include the lack of homogenous and constant information on performances rendered by public institutions, the eventual causal nexus between input, output and outcome, the farfrom-perfect transferability of corporate successes to the entire system, and the field's complexity [18]. Moreover, attention must be paid to the limits of universities (in this work, the limits of the Biomedical Branch): the 
impossibility for those in charge to rely on given specific levers such as remuneration levels, the definition of a stimulating system based on retributive flexibility, the rotation of internal personnel and, in part, the level of revenues (mostly funds).

The management of human resources within an organization endowed with such characteristics and limits, producing services highly affected by competences, skills and professionality addressed to a wide and heterogenous public, must be aimed at improving and increasing the capacities and competences of all its personnel.

The most suitable model to be used is thus focused on the personnel's competences, and combines two different approaches, i.e. the individual and the organic approach [19]: their integration allows for the qualitative professional growth of all employees (Figure 2).

The individual approach is centered on key personnel's organizational behaviour, operative capacities, personal skills and, in particular, around the identification of all competences, approaches and knowledge needed to such personnel for the achievement of more efficient results in activities which are crucial to the implementation of the corporate strategy.

The determination of competences is structured in such a way as to produce a list of personal characteristics and standards of reference. It is focused on the psychological dimension and concentrates on the technical capacities and skills of chosen key personnel. Hence, the idea of "competency" acquires different meanings according to the different contexts and realities it refers to: there is no absolute notion of competency, but rather a set of models relating to specific environments and professionalities.

The organic approach, instead, focuses on organizational competences and on objectively necessary skills for the development of all corporate processes, whether they are crucial or not. It is thus grounded on the strategic importance of each employee's contribution to the achievement of the entity's corporate mission, and it pursues the professional growth of all its personnel.

The model we have devised integrates the above two approaches by means of differentiated investment policies: on the one hand, these are focused on the needs of each key individual; on the other, these are objectively chosen in the light of the competences needed for the realization of all tasks required for all corporate processes.

It follows that the crucial point for the correct implementation of the model is the mapping of processes, which underpins both kinds of intervention.

Moreover, as regards the personal approach, the entity's key personnel is chosen by defining strategic themes grounded on the corporate mission and on a "swot" analysis [20].

Said themes are reported within the strategy map in order to stress the process of creation of value underpinning their definition, as well as the characteristics of the personnel which are needed to efficiently and effectively implement them. The entity's key personnel is thus a group of employees who, because of their personal characteristics and roles, are crucial in the management of all processes required for the implementation of strategic themes.

Once the crucial processes and the decisive roles for their implementation have been identified, the current competences of individuals carrying out such tasks must be assessed; such an assessment determines which actions are needed for their growth and quantifies in monetary terms what kind of investment is required for their realization.

The so-conceived evaluation is part of a report on human resources, which both assesses the competences and psychological-aptitude profiles needed to optimally implement the latter, and evaluates the actual competences of the structure's key employees, as well as any actions for their optimization. The description of the optimal profile of competences for each key role may also be used to promote internal personnel transfers and to employ unexploited talents within universities.

The evaluation of the current level of competences may be made by means of interviews and by adopting wide-ranging feedback techniques [21], these allowing for the evaluation of key employees' performances in terms of preparation, personal characteristics and aptitude. It is precisely these elements, in fact, which can bring about higher working performances within strategic tasks, in that they result in the capacity to work in a team, to establish and preserve constructive relationships and to guide and develop other employees' creativity.

The above assessment is grounded on quantitative rather than qualitative criteria; hence, it allows for comparisons between the level attained by each key employee and that required for each role by the entity's managing organs. It is thus possible to determine strategic initiatives aimed at bridging the gap between such two parameters, as well as a series of "lead" indicators representing their determining factors [22].

The practical realization of such strategic initiatives sets a feedback process in motion, which evaluates the 
effectiveness of all undertaken actions and provides for eventual changes in an effort to promote strategic advancements. In such a way, the university adopts a proactive, rather than merely reactive, approach with respect to the environment it is set in.

The evaluative and management process of human resources is then completed by establishing the cognitive needs of the entire workforce as a whole. This calls for the assessment of the competences needed to implement all internal management processes, as well as the continuative allocation of resources required to offer adequate training to all employees engaged in such processes. Moreover, training programmes ought to be promoted also upon the initiative of the concerned personnel, who can also be engaged in evaluating their effectiveness and adequacy.

\subsection{The Human Capital Report}

The creation of the Strategy Map underlines the connection between the above identified themes and the corporate mission, by representing the causal nexus which accounts for the strategic solutions adopted by the structure; furthermore, it points out the crucial processes needed for the achievement of the latter's basic aims. It follows that it is a necessary tool to identify the entity's key employees, who are fundamental for the management of such processes.

In the case at hand, the key employees of the structure are the General Manager at the head of the Branch and the many people in charge of the entity's offices, these playing a strategic role in the pursuit of the entity's aims whenever these fall within their own competence.

As far as the personal perspective is concerned, the initial investment in human resources should coincide with the evaluation and management of the entity's key personnel. The assessment process is grounded on the identification of all psychological-aptitudinal traits and competences necessary for the efficient and effective implementation of the structure's preestablished strategies.

Said identification is part of the report on human resources (Table 2), which divides personal characteristics into their three determining components, i.e. knowledge, abilities and aptitudes. The report indicates the ideal competences that key employees managing each strategic theme should be endowed with.

The report also presents strategic initiatives aimed at improving the level of performance in areas where the competences of key personnel are lacking, together with lead indexes, which express the determining factors of said initiatives. The evaluative results obtained by using such indexes provide perspective hypotheses as to the capacity of the structure to implement its strategic initiatives in the future, and thus place the Branch in a proactive, rather than merely reactive, approach towards the external environment [23].

Furthermore, in order for the importance of human resources to be turned into monetary investments whose effectiveness can also be judged in the structure's final budget, funding for each strategic initiative is to be determined and entered into the budget. Said investments are aimed at furthering knowledge and evidencing key employee's skills, as well as delineating the ideal profile for different strategic competences and potentially guiding the reallocation of personnel within the structure so as to allow unexploited talents to emerge.

Lastly, the assessment and management of the structure's key personnel needs to be supplemented with investments addressed to the entire staff, aimed at the growth of the Branch's entire workforce. Such investments are to be programmed by examining all internal management processes (not only the crucial ones) so as to establish the personnel's cognitive knowledge on the basis of each employee's role and respective office. It is believed that training initiatives should also be defined by those directly concerned, who are then to be asked to quantitavely assess the effectiveness of training by answering to questionnaires and interviews.

There is a wide range of training courses which can be offered to employees, including e.g. language courses for employees engaged in international relations, and updating courses on fiscal law for employees working in financial-accounting offices. It is also possible to conceive courses addressed to the entire workforce aimed at explaining given areas of labour law which employees might be particularly interested in, such as safety on the workplace.

\section{Conclusions}

The ongoing profound changes which are affecting Italian Universities are to be set within the wider transformation process of the conception and management of the supply of services by Public Administrations. In particular, the need to attain greater financial autonomy has prompted such entities to introduce economic-business logics and processes which radically differ from those adopted in the past. 
The "Branches" project has been conceived by the University of Florence as a response to such external changes. It provides for a decentralization process which strives to confer flexibility to administrative structures and is tailored to offer decentralized services directly supporting didactic and research centres.

The project is based on the realization that the University is the heart of territorial economic and social development and must therefore stand as a reference point for all innovation processes. In Italy, however, the study of said matters has not been as extensive as in Anglosaxon countries.

In the light of such considerations, our work suggests an innovative system for the assessment and management of performances rendered by the University's primary immaterial resource, i.e. human resources. The model is grounded on Strategy Maps which allow for the evaluation of the alignment of such an asset to the corporate strategy and for the maximization of the value of investments made in this respect.

Investments in human resources are divided into a personal and a social component, directed to the entity's key personnel and to the entire staff respectively; this strengthens, albeit in different ways, both the role of employees carrying out key tasks for the achievement of strategic aims, and the role of employees carrying out tasks and roles of low-medium importance.

Our model aims at regulating and controlling the variability of individual and collective components in response to normative and market developments. It also aims at placing the single worker within corporate aims, guaranteeing the development and importance of employees' competences, and moving from a purely hierarchical logic in corporate relationships to a consensus-oriented and responsibility-sharing approach.

The assessment of performances is not to be seen as a supporting instrument of retributive policies, but rather as an instrument for the development of the structure's personnel, aimed exclusively at improving the performances of the individual assessed.

The ultimate goal of the model is to obtain a working environment in which each individual, independently of his hierarchical level, pursues the same aim, i.e. stakeholder satisfaction, and acts autonomously in the best way, sharing such aim and being aware of it, and realizing how and to what extent his behavior may affect the results of the entire corporate structure.

The limitation of this study is that the research involves a single case study and the investigation is based on the specific structure of the University of Florence so the generalization of our model must be considered with caution. However, the case study includes details on specific services (financial, research and didactic services) common to all universities.

Consequently, the case study analysis is useful for similar organizations interested in designing and implementing the strategy map and the human capital report.

Future research is suggested on applying a version of human capital report developed by the Biomedical Branch of University of Florence at other university institutes.

\section{References}

[1] Jassbi, J., Mohamadnejad, F. and Nasrollahzadeh, H. (2011) A fuzzy DEMATEL Framework for Modeling Cause and Effect Relationships of Strategy Map. Expert Systems with Applications, 38, 5967-5973. http://dx.doi.org/10.1016/j.eswa.2010.11.026

[2] O’Neil, H.F., Bensimon, E.M., Diamond, M.A. and Moore, M.R. (1999) Designing and Implementing an Academic Scorecard. Change, 31, 32-40. http://dx.doi.org/10.1080/00091389909604231

[3] Cullen, J., Joyce, J., Hassall, T. and Broadbent, M. (2003) Quality in Higher Education: From Monitoring to Management. Quality Assurance in Education, 11, 5-14. http://dx.doi.org/10.1108/09684880310462038

[4] Chen, S.H., Yang, C.C. and Shiau, J.Y. (2006) The Application of Balanced Scorecard in the Performance Evaluation of Higher Education. The TQM Magazine, 18, 190-205. http://dx.doi.org/10.1108/09544780610647892

[5] Papenhausen, C. and Einstein, W. (2006) Insights from the Balanced Scorecard Implementing the Balanced Scorecard at a College of Business. Measuring Business Excellence, 10, 15-22. http://dx.doi.org/10.1108/13683040610685757

[6] Kettunen, J. (2006) Strategic Planning of Regional Development in Higher Education. Baltic Journal of Management, 1, 259-269. http://dx.doi.org/10.1108/17465260610690917

[7] Kargozar F.R.N. (2016) Objectives Priority in University Strategy Map for Resource Allocation. Benchmarking: An International Journal, 23, 371-387.

[8] Philbin, S.P. (2011) Design and Implementation of the Balanced Scorecard at a University Institute. Measuring Business Excellence, 15, 34-45. http://dx.doi.org/10.1108/13683041111161148 
[9] Kaplan, R.S. and Norton, D.P. (1996) The Balanced Scorecard-Translating Strategy into Action. Harvard Business School Press, Boston.

[10] Baccarini, C. (1999) L’università tra cambiamento e conservazione. Sinergie, No. 48.

[11] Fici, L. (2001) Il controllo di gestione negli atenei. Dalla valutazione al governo aziendale, Franco Angeli, Milano.

[12] Phillips, J.J. and Schimdt, L. (2003) Implementing Training Scorecards (In Action). ASTD Press, Alexandria.

[13] Lev, B. and Daum, J.H. (2003) The Dominance of Intangible Assets into Tangible Outcomes. Harvard Business School Press, Boston.

[14] Kaplan, R.S. and Norton, D.P. (2004) Strategy Maps-Converting Intangible Assets into Tangible Outcomes. Harvard Business School Press, Boston.

[15] Niven, P.R. (2003) Balanced Scorecard Step-by-Step for Government and Non Profit Agencies. John Wiley \& Sons, New York.

[16] Friedag, H.R. and Schmidt, W. (2002) Balanced Scorecard. Mehr als ein Kennzahlensystem, Freiburg i.Br.

[17] Caccia, L. (2003) Il PEG oltre la gestione per obiettivi: Idee perla progettazione, in AA. VV. La gestione economica e finanziaria degli enti locali, ICA, Trento.

[18] Fici, L. (2000) Le potenzialità del PEG quale strumento di budgeting. Verso una programmazione basata sulle attività, Azienda Pubblica, n. 2/3, 217-233.

[19] Steward, T.A. (1997) Intellectual Capital: The New Wealth of Organizations. Nicholas Breadley Publishing, London.

[20] Andriessen, D. (2004) Making Sense of Intellectual Capital: Designing a Method for the Valuation of Intangibles. Butterworth Heinemann, Boston.

[21] De Nisi, A. and Kluger, A. (2000) Feedback Effectiveness: Can 360-Degree Appraisals Be Improved?” (ed. It. “L’efficacia del feedback: È possibile migliorare I sistemi di valutazione a 360 gradi?”). Problemi di Gestione, XXIII, No. 2.

[22] Ulrich, D. and Brocbank, W. (2005) The HR Value Proposition. Harvard Business School Press, Boston.

[23] Marr, B., Schiuma, G. and Neely, A. (2004) The Dynamics of Value Creation-Mapping Your Intellectual Performance Drivers. Journal of Intellectual Capital, 5, 312-325. http://dx.doi.org/10.1108/14691930410533722

\section{Submit or recommend next manuscript to SCIRP and we will provide best service for you:}

Accepting pre-submission inquiries through Email, Facebook, LinkedIn, Twitter, etc.

A wide selection of journals (inclusive of 9 subjects, more than 200 journals)

Providing 24-hour high-quality service

User-friendly online submission system

Fair and swift peer-review system

Efficient typesetting and proofreading procedure

Display of the result of downloads and visits, as well as the number of cited articles

Maximum dissemination of your research work

Submit your manuscript at: http://papersubmission.scirp.org/ 